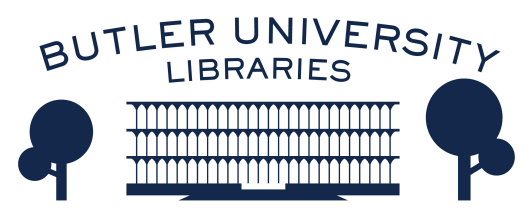

Journal of Hindu-Christian Studies

\title{
Book Review: The Problem with Interreligious Dialogue: Plurality, Conflict, and Elitism in Hindu-Christian-Muslim Relations
}

Anantanand Rambachan

Saint Olaf College

Follow this and additional works at: https://digitalcommons.butler.edu/jhcs

Part of the Christianity Commons, Hindu Studies Commons, and the Religious Thought, Theology and Philosophy of Religion Commons

\section{Recommended Citation}

Rambachan, Anantanand (2017) "Book Review: The Problem with Interreligious Dialogue: Plurality, Conflict, and Elitism in Hindu-Christian-Muslim Relations," Journal of Hindu-Christian Studies: Vol. 30, Article 28.

Available at: https://doi.org/10.7825/2164-6279.1680

The Journal of Hindu-Christian Studies is a publication of the Society for Hindu-Christian Studies. The digital version is made available by Digital Commons @ Butler University. For questions about the Journal or the Society, please contact cbauman@butler.edu. For more information about Digital Commons @ Butler University, please contact digitalscholarship@butler.edu. 
suffering in the Holocaust. Hugh Nicholson responds to Bidlack and Moyaert by first pointing out the methodological differences between the two essays and proceeds to respond to each on its own terms. Bidlack, starting from a point of similarity between Christian and Daoist texts goes on to show that careful study of two texts and traditions belies first impressions. Moyaert, starting from a point of tension between two religious traditions, shows how the interpretation of particular doctrines can shape a community.

Part five, on Way(s) of Salvation, features an essay by Joshua Ralston that, building upon the work of Mark Heim, suggests that there are multiple understandings of salvation that are, in fact, in competition with each other and that cannot be categorically lumped together. The essay goes on to compare the specific "ways" or "laws" presented in the work of Protestant reformer John Calvin and the Sunni theologian, Abu Hamid al-Ghazali. The second essay here, by Sharon V. Betcher, considers the soteriological promises presented by the Hindu "spiritual but not religious" guru figure, Deepak Chopra. Chopra turns away from traditional categories of the eternal and transcendent towards the embodied individual and the power of positive thinking. This analysis is then compared with the work of theologian Catherine Keller, who insists on the spiritual centrality of "com/passion" as communal and other oriented. Shelly Rambo responds to Ralston and Betcher by rightly pointing out that both authors focus on the "path and process of salvation," such that "salvation is about a broader orientation to the life of faith." (297) This approach, Rambo suggests, reaffirms peacemaking as a central goal for interreligious dialogue and comparative theology.

This volume is the result of a conference held at Wake Forest University School of Divinity in 2014. As a whole, it would be a very interesting companion volume for a course in systematic theology or a world religions course that wants to emphasize dialogue. As noted by Voss Roberts in her introduction, there are also patterns of thought that stretch across the sections, such as divine immanence, and the need for ethical and ecological responsibility. The five sections of the book also make accessible the possibility of introducing a comparative element into a more specialized course. In addition to being a fine teaching tool, this is a masterful collection of essays from some of the leading scholars in the field of comparative theology.

Stephanie Corigliano

Humboldt State University

\section{The Problem with Interreligious Dialogue: Plurality, Conflict, and Elitism in Hindu-Christian-Muslim Relations. By Muthuraj Swamy. London: Bloomsbury Academic, 2016, xvi + 230 pages.}

BASED on fieldwork conducted in the Kanyakumari district in India (2007-2008), Muthuraj Swamy offers a critique of interreligious dialogue in India focused in three principal areas. His critique is based on a distinction between the interreligious dialogue 
occurring among religious elites (leaders, thinkers and theologians) and the so-called "grassroots." Swamy does not offer a definition of "grassroots," but describes the elites as those " who think that formal dialogue should be propagated because it can bring better relationships (and negotiations) between each other irrespective of having multiple identities" (p. 17). The grassroots, on the other hand, are "those who maintain relationships (and negotiations) between each other irrespective of having multiple identities" (p. 17). The grassroots are generally targeted by the elites for instruction and direction about dialogue.

The first limitation of interreligious dialogue in India, according to Swamy, is its uncritical adoption of the language of "religions," "world religions," and the secularreligious dualism. These categories and distinctions are not interrogated by elites and their character as western constructs little understood. Drawing on postcolonial theory and the seminal work of Edward Said, Swamy reiterates the argument that these constructs serve the purpose of imperial domination. The idea of religion "is rooted in the Christian West which was developed in the Hellenistic context" (p. 74). In a similar way, the idea of religion as a distinct category of human life "is a modern myth created during the European Enlightenment in the seventeenth and eighteenth centuries" (p. 74). This Christianized model of religion privileges doctrines, written texts and exegesis. In the case of the Hindu tradition, such colonizing processes led to the idea of a homogenous religion. "This is a crucial point, because while there were a number of traditions, known as religious, among people in India, only a few of them were selected to be 'the Hindu religious system'. It included mostly the traditions deriving from the Vedas, Vedantas, and Upanishads to which the upper-caste people such as Brahmins belonged" (p. 87).

One of the important observations of Swamy in this regard is appropriation of these constructs by Indian Christian theologians who are regarded as pioneers in the development of an indigenous Christianity in India. These include well-known figures such as K. C.Sen, Krishna Mohan Banerjee, Brahmabandhab Upadyaya, A.S. Appasamy, and Sadhu Sundar Singh. "Even though the terms suggested that they were attempting to relate Christianity to India or to reinterpret and embed Christianity in Indian traditions, what they were actually doing was a Hinduization of Christianity - a Hinduism based on dominant upper-caste traditions" (p. 89).

What are the implications for interreligious dialogue when these constructs are assumed? Dialogue that proceeds from the idea of homogenized identities, notes Swamy, downplays the complex intra-religious identities of people, ignores those identities that transcend religious boundaries, and underestimates " the ability of individuals to construct religious identities for themselves and to use them consistently in their dealings with other individuals" (p. 102). People at the grassroots, Swamy argues, "cross religious boundaries in constructing their own as well as others' identities" (p. 102).

The second limitation of dialogue in India highlighted by the author is concerned with the nature of religious conflicts. Not unrelated to the categorization of "religion," here the issue is uncritical assumption that "religion" or "religions" are the sources of violence. This leads to religious elites proposing that the purpose of dialogue is the overcoming of 
religious conflict and the realization of "communal harmony." Drawing in a special way from his study of the Mandaikadu religious conflicts in the Kanyakumari district (1982), Swamy contests this claim. It ignores the fact that the so-called "religious violence" almost always has social and economic roots and overlooks "the political intervention which plays with the religious identities of the people in order to boost vote-bank politics" (p. 8).

My argument is that it is not the misunderstanding of religion or the political use of religion that are solely responsible for religious conflicts. Rather, it is the naming conflicts among individuals and groups, who live with multiple religious identities, as religious for vested interests that is crucial. The dialogue promoters seldom recognize this when talking about either religions causing conflict or religious people being instruments in the hands of politicians creating conflicts (p. 121).

We need more focus on the vested interests who benefit when a conflict with socioeconomic causes is labeled "religious."

The third limitation of dialogue in India discussed by Swamy has to do with what he regards at its elite nature and methods. The consequence is that the grassroots are "silent objects" of these conversations. The reality of their living relationships is ignored and there is little interest in learning from the life experiences in local communities. Elite dialogue is a top-down process that ignores the fact of multiple identities among the common people.

The problems of interreligious dialogue that Swamy discusses in this work (the construction of religion/religions and fixed identities; the understanding of conflict as religious and elitism) are not unknown observations. The special contribution of this study is the challenge of these assumptions about dialogue by his empirical work at the ground level. He successful demonstrates the fluidity and complexity of relationships and the ways in which such relationships may be more successful in overcoming communal tensions and conflicts. This dimension of Swamy's work grants it a relevance that goes beyond the Indian context. Interreligious dialogue is certainly diminished when it is isolated and disconnected from relations obtaining among human beings in community. Theories about dialogue need the interrogation and critique of practice. This book is a welcome addition to critical literature on interreligious dialogue and makes a strong case for more studies that are empirically based.

Anantanand Rambachan

Saint Olaf College

\section{The Future of Hindu-Christian Studies: A Theological Inquiry. By Francis X. Clooney, S.J. London and New York: Routledge, 2017, xi + 135 pages.}

THIS book consists of what are known as the Westcott-Teape Memorial Lectures (after the names of the person in whose honor the lectures were endowed and the donor) delivered by
Professor Francis X. Clooney, SJ, of Harvard Divinity School at Delhi, Kolkata, and Chennai in India and at the University of Cambridge in U.K. during 2015-16. This lecture series, starting in 